\title{
Застосування кількісних експрес-тестів для визначення протромботичних та інших маркерів несприятливих подій у реаліях COVID-19
}

\author{
O.І. Осадчий \\ Редакція журналу «Український медичний часопис»
}

Лабораторні тест-системи для проведення кількісного експрес-аналізу із застосуванням імунофлуоресцентного методу на основі тест-смужок знаходять все більше клінічне застосування. Використання «сухого» методу хімічного аналізу дозволило максимально спростити процедуру та отримати аналізи експертного рівня якості. Наведене повною мірою стосується аналізатора «Finecare ${ }^{\mathrm{TM}}$ FIA Meter» («Wondfo®», Китай). Актуальність цих приладів особливо відчутна під час пандемії COVID-19.

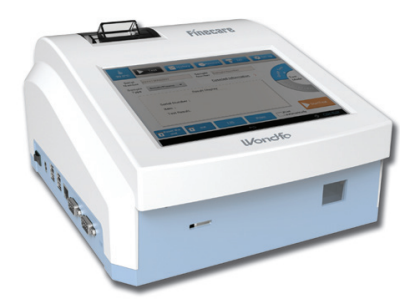

За даними Всесвітньої організації охорони здоров'я, станом на 03.02.2021 р. в усьому світі зареєстровано 103362039 підтверджених випадків COVID-19, який призвів до 2244713 смертей [1]. Серед причин летального кінця - тяжка бактеріальна пневмонія, гострий респіраторний дистрес-синдром із поліорганною недостатністю, розвиток тромбоемболічнихускладнень, які зазвичай спричиняються порушенням коагуляційної здатності системи гемостазу на тлі активації гіперкоагуляції та підвищеної тромбогенності крові [2-5]. У хворих із тяжким перебігом COVID-19 виявляють значно вищі рівні C-реактивного білка (СРБ), прокальцитоніну (ПКТ), D-димера, сироваткового амілоїду A, інтерлейкіну-6 та -10 порівняно із хворими з легким та помірним перебігом [6]. Зазначені показники мають прямий кореляційний зв'язок із погіршенням стану пацієнта і прогнозують високу ймовірність летального кінця [7]. Саме тому кожний із цих показників сьогодні розгляда$\epsilon$ ться як провісник розвитку загрозливих станів, і водночас $\epsilon$ надійним маркером для контролю лікувальних заходів.

Так, >7-кратне підвищення рівня D-димера у хворих із тяжким перебігом COVID-19 на тлі зростання концентрації фібриногену та збільшення протромбінового часу і тромбоцитопенії слугувало провісником підвищення летальності майже вдвічі [8-10]. Його підвищення асоційоване зі зростанням частоти загрозливих тромбоемболічних ускладнень, особливо серед пацієнтів із тромбофілією чи тромботичним минулим в анамнезі [11]. Важливим провісником очікуваного тяжкого стану або погіршання перебігу захворювання $\epsilon$ рівні гострофазових білків - СРБ та ПКТ. Їх підвищена концентрація у крові, яка спостерігається у найближчі часи гострого запального процесу, $є$ доволі надійним прогностичним фактором. Їх діагностична цінність особливо відчутна у разі прогнозування розвитку таких тяжких станів, як сепсис, поліорганна недостатність та цитокіновий шторм [12]. Останній $\epsilon$ важливою ланкою патогенетичного розвитку погіршення клінічного стану хворих на COVID-19. Так, клініко-лабораторна оцінка концентрації ПКТ з урахуванням клінічного стану хворого при гострих респіраторних вірусних інфекціях, зокрема при COVID-19, може мати вирішальне значення для своєчасного призначення і тривалості антибактеріальної терапії [13, 14].

Сьогодні методи лабораторного визначення тих чи інших біохімічних/хімічних маркерів, які доводили би розвиток загрозливих порушень в організмі хворого та ймовірність розвитку негативних подій, стали невід'ємною частиною стратифікації ризиків лікувального процесу. Особливо актуальним питання якісної та своєчасної лабораторної діагностики постало під час пандемії COVID-19. Такі показники, як D-димер та ПКТ, - серед обов'язкових тестів у пацієнтів із COVID-19 [15]. Однак їх масове впровадження без сучасних технологічних рішень малоймовірне. Зарадити цьому можуть сучасні прилади, які забезпечують мініатюризацію процесів аналізу зі збереженням надійності та інформативності їх результатів. Зазвичай для цього використовують:
- тест-смужки (метод «сухої хімії»);

- картриджі, слайди (метод імунохроматографіі);

- біосенсори - токопровідні смужки (метод потенціометріі);

- латексні тест-системи.

Прилади на основі зазначених технологій не потребують для обслуговування висококваліфікованого персоналу і дозволяють проводити лабораторні дослідження навченим медичним персоналом безпосередньо біля ліжка хворого (англ. point-of-care testing). Це дозволяє максимально скоротити час проведення дослідження та отримання відповіді на поставлене клінічне завдання, спростити процедуру проведення дослідження та зробити іiі доступною для медичного персоналу без спеціальної аналітичної освіти. Більшість пристроїв дозволяє отримати візуальну інформацію результатів тестування миттєво, що стало вирішальним у виборі сфери їх застосування: відділення невідкладної допомоги та карети швидкої допомоги, палати інтенсивної терапії лікувальних закладів загального профілю, кабінети сімейного лікаря та для особистого домашнього застосування. Наведені аргументи сприяли стрімкому поширенню портативних клінічних аналізаторів серед медичних закладів.

Серед приладів, які знайшли широке клінічне застосування, зокрема в Україні, — лабораторне обладнання компанії «Wondfo » (Китай) - система «Finecare ${ }^{\mathrm{TM}}$ FIA Meter» для проведення кількісного експрес-аналізу із застосуванням імунофлуоресцентного методу (на основі використання тест-смужок для «сухого» хімічного аналізу). Система здатна допомогти в діагностиці таких станів, як запалення, сепсис, цукровий діабет, серцево-судинні захворювання, ураження нирок, онкологічні захворювання тощо. Аналізатор надає можливість провести дослідження крові та сечі впродовж декількох хвилин за 36 показниками, серед яких:

- тести на запалення (ПКТ, СРБ, сироватковий амілоїд А);

- маркер коагуляції D-димер;

- кардіомаркери (мозковий натрійуретичний пептид, тропонін I та ін.);

- глікозильований гемоглобін;

- маркери ураження нирок (мікроальбумін, цистатин-С, ренальний тропонін, $\beta_{2}$-мікроглобулін);

- оріонічний гонадотропін;

- широкий спектр гормонів (12 показників);

- вітамін D.

Клінічне застосування зазначеного приладу може забезпечити ретельний контроль лікувального процесу на всіх етапах: від моменту госпіталізації до виписки та амбулаторного спостереження. 